\title{
Effect of Indium Additions on the Formation of Interfacial Intermetallic Phases and the Wettability at Sn-Zn-In/Cu Interfaces
}

\author{
Janusz Pstruś, Tomasz Gancarz, and Przemyslaw Fima \\ Institute of Metallurgy and Materials Science, Polish Academy of Sciences, Ul. Reymonta 25, 30-059 Krakow, Poland \\ Correspondence should be addressed to Janusz Pstruś; j.pstrus@imim.pl
}

Received 28 April 2017; Revised 19 June 2017; Accepted 17 August 2017; Published 1 October 2017

Academic Editor: Michael Aizenshtein

Copyright (C) 2017 Janusz Pstruś et al. This is an open access article distributed under the Creative Commons Attribution License, which permits unrestricted use, distribution, and reproduction in any medium, provided the original work is properly cited.

\begin{abstract}
The wettability of copper substrates by Sn-Zn eutectic solder alloy doped with $0,0.5,1$, and 1.5 at.\% of indium was studied using the sessile drop method, with flux, in air, at $250^{\circ} \mathrm{C}$ and reflow time of $3,8,15,30$, and $60 \mathrm{~min}$. Wetting tests were performed at $230,250,280,320$, and $370^{\circ} \mathrm{C}$ for an alloy containing 1.5 at.\% of indium, in order to determine activation energy of diffusion. Solidified solder/substrate couples were studied using scanning electron microscopy (SEM), the intermetallic phases from $\mathrm{Cu}-\mathrm{Zn}$ system which formed at the solder/substrate interface were identified, and their growth kinetics was investigated. The $\varepsilon$-CuZn $\mathrm{n}_{4}$ was formed first, as a product of the reaction between liquid solder and the $\mathrm{Cu}$ substrate, whereas $\gamma-\mathrm{Cu}_{5} \mathrm{Zn}_{8}$ was formed as a product of the reaction between $\varepsilon$-CuZn ${ }_{4}$ and the $\mathrm{Cu}$ substrate. With increasing wetting time, the thickness of $\varepsilon$-CuZn ${ }_{4}$ increases, while the thickness of $\varepsilon-\mathrm{CuZn}_{4}$ does not change over time for indium-doped solders and gradually disappears over time for $\mathrm{Sn}$ - $\mathrm{Zn}$ eutectic solder.
\end{abstract}

\section{Introduction}

The continuous development of microelectronics in respect to miniaturisation and improved efficiency motivates the search for new materials and technologies capable of allowing both cost reductions and increased density of connections and efficiency, along with improved reliability. The European Parliament and the Council of Europe directives issued in [13] 2003 and in 2008 prohibited the use of solders containing metals such as lead and cadmium, which are detrimental to human health. Therefore, in recent years intense research has been conducted worldwide, the aim of which is to devise new alternatives to hazardous solders such as those containing lead.

Interest in alloys based on $\mathrm{Sn}-\mathrm{Zn}$ eutectic is the result of the search for the optimum replacement of $\mathrm{Pb}$-Sn solders. Sn$\mathrm{Zn}$ eutectic's greatest advantages are its low melting temperature $\left(198^{\circ} \mathrm{C}\right)$, which is close to the melting temperature of $\mathrm{Pb}$ Sn eutectic, and the low cost per mass unit. In addition, $\mathrm{Sn}-\mathrm{Zn}$ alloys exhibit relatively high mechanical strength, corrosion resistance, and resistance to thermal fatigue [4-8]. On the other hand, these alloys wet soldered surfaces poorly and are prone to oxidation unless soldering is carried out under a protective atmosphere or with a sufficiently aggressive flux [9-11]. Well-chosen alloying additions may improve joint properties, so in designing joints it is essential to understand the effect of alloying additions on processes occurring at the interface of solder and substrate. The addition of indium may lower the melting temperature of solders but also improve the wettability and durability of solder joints [12]. We earlier investigated the effect of indium addition on the properties of soldered joints: $\mathrm{Cu} / \mathrm{SnAgCu}+\mathrm{In}$ [13], Ni/Sn-Zn + In [14], and to some extent $\mathrm{Cu} / \mathrm{Sn}-\mathrm{Zn}+\mathrm{In}[15,16]$. In the case of $\mathrm{Cu} / \mathrm{SnAgCu}+\mathrm{In}$ [13], it was found that the $\mathrm{Cu}_{6} \mathrm{Sn}_{5}$ was formed at the solder/Cu interface for solders with low In concentration, whereas for high In concentrations it was the $\mathrm{Cu}_{41} \mathrm{In}_{11}$ phase that developed. Also, higher In content leads to the formation of In-based phases $\left(\mathrm{InSn}_{4}\right)$, which in turn hinder the diffusion of $\mathrm{Cu}$ and resulted in the decreased thickness of the interfacial $\mathrm{Cu}$-rich layer [13]. The addition of 
In to $\mathrm{Sn}-\mathrm{Zn}$ eutectic leads to a lower wetting angle on $\mathrm{Ni}$ and $\mathrm{Cu}$ substrates [14]. Earlier [15], we found that the spreading area increases with In content over a relatively short wetting time, but for longer wetting times this effect was absent.

The authors of [16] studied the effect of indium on the surface tension, electrical conductivity, and viscosity of liquid In-Sn, and the correlation between these properties and the structure of the liquid. They found anomalies in concentration dependence of viscosity near indium concentrations corresponding to intermetallic phases existing in the In-Sn system.

Taking the above into account, the aim of this work is to investigate the effect of indium addition to $\mathrm{Sn}-\mathrm{Zn}$ eutectic on spreading on copper substrates, as well as on the phenomena occurring at solder/substrate interface during soldering.

\section{Experimental}

For wetting tests, copper substrates (99.9 wt.\%, Alfa-Aesar) were used and their surfaces prepared in accordance with EN ISO 9455-10:2000. Copper plates $(40 \times 40 \times 0.25 \mathrm{~mm})$ were etched in $99.5 \%$ copper sulphide solution for $8 \mathrm{~min}$, subsequently ground with sand paper $(1,000)$, and degreased with methyl alcohol and acetone directly before wetting tests.

Alloys were prepared by melting carefully weighed amounts of pure (99.999 wt.\%) Sn, Zn, and In in alumina crucibles under high purity (99.9999 vol.\%) Ar atmosphere. The wetting tests were carried out with the use of the apparatus earlier described in [17], at $250^{\circ} \mathrm{C}$, for different annealing times $(3,8,15,30$, and 60 minutes), without a protective atmosphere and with the use of the Alu- $33^{\circledR}$ flux produced by Amasan. According to ISO 9454-1, this is a 2.1.2-type flux, that is, organic, water-soluble, and activated with halides. In order to determine the activation energy of the growth of the $\mathrm{Cu}_{5} \mathrm{Zn}_{8}$ phase for an alloy containing 1.5 at.\% of indium, wetting test were performed at 230, $250,280,320$, and $370^{\circ} \mathrm{C}$. For each set of the experimental conditions (sample composition, temperature, and time) 5-7 independent wetting tests were performed. Solidified samples were washed with tap water to remove flux residue and photographed from two perpendicular directions. Wetting angle data are the average of individual measurements for all samples. The wetting angles were determined from photographs using the application ImageJ. The spreading areas of solders were determined from photographs of the top view of drops. Selected solidified solder/substrate couples were cut perpendicular to the plane of the interface, mounted in conductive resin, polished for microstructural characterisation, and sputtered with a thin carbon layer. Microstructural and energy-dispersive spectroscopy (EDS) analysis was performed with the FEI E-SEM XL30 system, at $20 \mathrm{kV}$, with the use of the standardless Analysis EDAX System based on Genesis 2000 software. The intermetallic phases of $\mathrm{CuZn}_{4}$ and $\mathrm{Cu}_{5} \mathrm{Zn}_{8}$ were identified based on analysis of results EDS and knowledge of the binary $\mathrm{Cu}-\mathrm{Zn}$ phase diagram. The thickness of intermetallic (IMC) layers was determined from micrographs with the use of ImageJ software.

\section{Results and Discussion}

Figure 1(b) illustrates the wetting angle of Sn-Zn-In alloys on copper substrate at $250^{\circ} \mathrm{C}$, for varying indium content and time. It is clear that the wetting angles of In-doped alloys are lower than those of the alloy without In addition. This difference is more pronounced than in our earlier work [14], where we also found that the wetting angle decreased with increasing temperature. However, this earlier investigation was carried out with different flux. For the alloys in the present study, the wetting angle seems to be practically independent of wetting time. Similarly, we earlier [15] observed, with the use of the same flux as in this study, that the spreading area does not increase over time. Figure 1(a), based on the example of an alloy containing $1.5 \%$ of In, illustrates that the spreading area increases with increasing temperature

$$
\sigma_{\mathrm{SV}}=\sigma_{\mathrm{SL}}+\sigma_{\mathrm{LV}} \cos \phi
$$

According to the Young-Dupre equation (1), as illustrated in Figure 2, wettability can be improved (wetting angle $\phi$ lowered) by increasing the surface energy of the solid substrate $\sigma_{\mathrm{SV}}$, by lowering the surface tension of the liquid alloy $\sigma_{\mathrm{LV}}$, or by lowering solid-liquid interfacial tension $\sigma_{\mathrm{SL}}$. The increase of surface energy of solid $\sigma_{\mathrm{SV}}$ occurs as the oxide layer is removed by flux action. The surface tension of the alloy, on the other hand, can be lowered by doping with surface active components or metals with substantially lower surface tension. From Figure 1 we can conclude that, with increasing In content, the wettability improves, despite the fact that authors of $[16,18]$ did not observe surface tension decreasing with indium concentration. The authors of [13] claim that increasing concentration of In in liquid solder (Sn$\mathrm{Ag}-\mathrm{Cu}$ alloy in their case) improves wettability on copper. This is because In lowers solid-liquid interfacial tension, even if it does not lower the surface tension of the solder.

Figure 1(b) presents the spreading area of $(\mathrm{SnZn})_{\text {eut }}+1.5 \%$ at. In solder on Cu after 8 min of wetting at 230, 250, 280, 320, and $370^{\circ} \mathrm{C}$. It is clear that the spreading area increases with temperature, which could be a result of the surface tension of Sn-Zn-In alloy decreasing with temperature [18] and may also be due to changes in interfacial tension.

After wetting tests, the microstructure of the solder/Cu interface of selected samples was investigated. According to Lee et al. [19], Gibbs free energy of the formation of the $\gamma-\mathrm{Cu}_{5} \mathrm{Zn}_{8}$ phase is $-212.10 \mathrm{~kJ} / \mathrm{mol}$ (at $150^{\circ} \mathrm{C}$ ), while Gibbs free energy of the formation of $\mathrm{Cu}_{6} \mathrm{Sn}_{5}$ is $-26.26 \mathrm{~kJ} / \mathrm{mol}$, which explains why the intermetallic phase from the $\mathrm{Cu}-\mathrm{Zn}$ system is formed at the liquid $\mathrm{Sn}-\mathrm{Zn}$ /solid $\mathrm{Cu}$ interface. At $250^{\circ} \mathrm{C}$, in the $\mathrm{Sn}-\mathrm{Zn}$-Cu system the liquid phase (composition close to eutectic $\mathrm{Sn}-\mathrm{Zn}$ ) coexists in equilibrium with two intermetallic phases: $\gamma-\mathrm{Cu}_{5} \mathrm{Zn}_{8}$ and $\varepsilon$-CuZn $4[20,21]$. In a study of $\mathrm{Sn}-\mathrm{Zn}-\mathrm{Cu} / \mathrm{Cu}$ interfaces over short wetting time [22], we found that, at the earliest stage of the soldering process, liquid solder reacts with the $\mathrm{Cu}$ substrate and $\varepsilon-\mathrm{CuZn}_{4}$ is formed. After $60 \mathrm{~s}$, as a result of the diffusion of elements, $\boldsymbol{\gamma}$ $\mathrm{Cu}_{5} \mathrm{Zn}_{8}$ starts to appear. In the present study, both $\varepsilon$-CuZn and $\gamma-\mathrm{Cu}_{5} \mathrm{Zn}_{8}$ were found at the solder/substrate interface.

Figures 3 and 4 , respectively, illustrate the interfacial microstructure of $\mathrm{Sn}-\mathrm{Zn} / \mathrm{Cu}$ and $\mathrm{Sn}-\mathrm{Zn}-1.5 \% \mathrm{In} / \mathrm{Cu}$ couples 


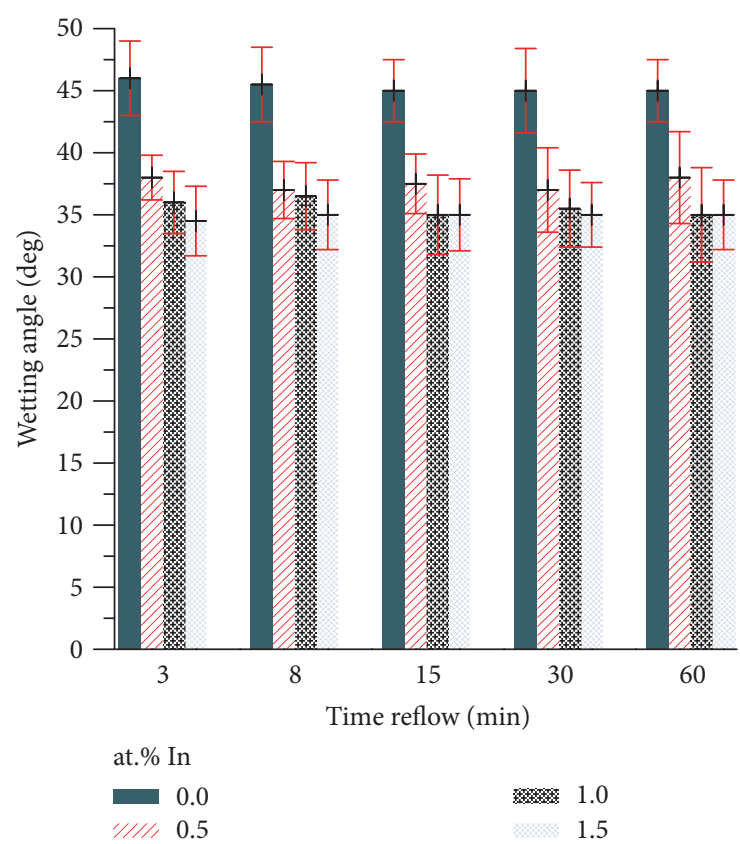

(a)

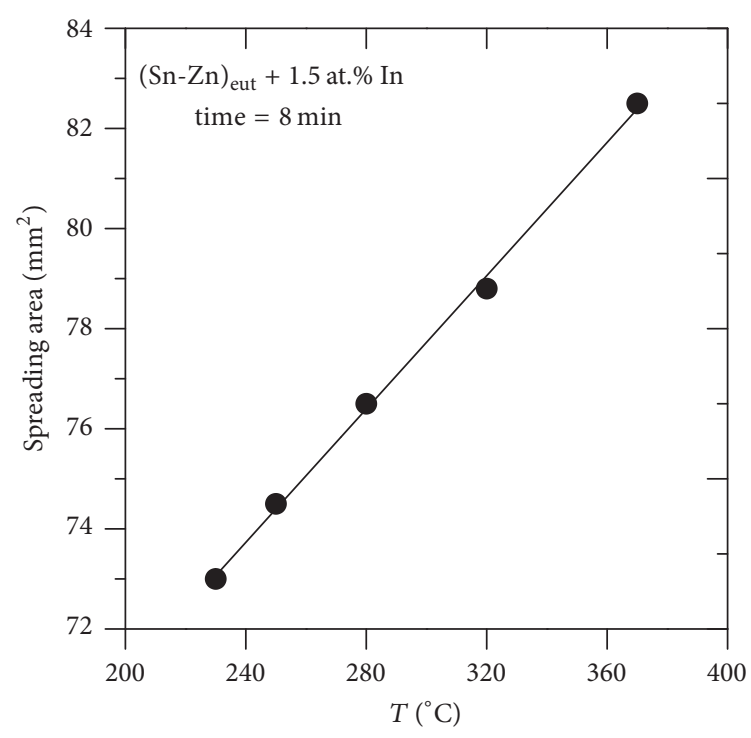

(b)

Figure 1: Wetting angle (a) and spreading area (b) of $0.5 \mathrm{~g}$ liquid $\mathrm{Sn}-\mathrm{Zn}-x \operatorname{In}(x=0,0.5,1,1.5)$ on copper substrate: (a) $250^{\circ} \mathrm{C}, 3-60 \mathrm{~min},(\mathrm{~b})$ $230-370^{\circ} \mathrm{C}, 8 \mathrm{~min}$.

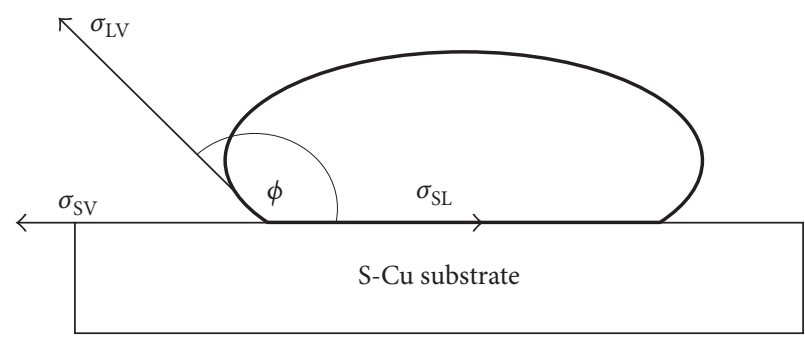

(a)

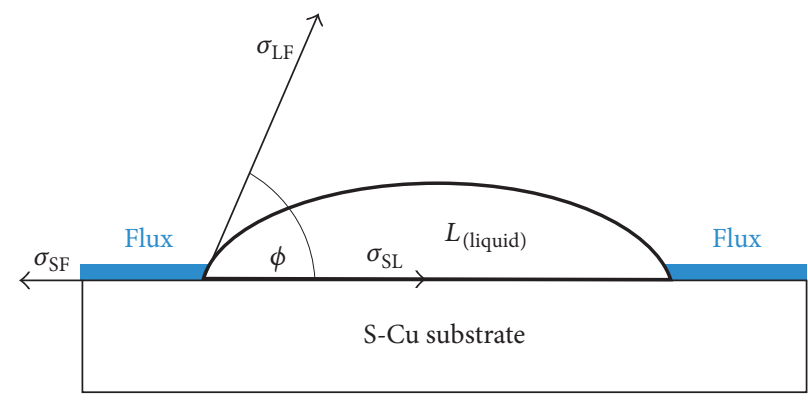

(b)

FIGURE 2: Sketch of Young-Dupre equation.

after (a) 3, (b) 15 , and (c) $30 \mathrm{~min}$ at $250^{\circ} \mathrm{C}$. The growth of intermetallic layers over time at the solder/substrate interface of the abovementioned couples is illustrated in Figure 5. For both examples, there are two intermetallic phases at the interface in the early stage (up to $15 \mathrm{~min}$ ). These are $\varepsilon$ - $\mathrm{CuZn}_{4}$ on the side of the solder and $\gamma-\mathrm{Cu}_{5} \mathrm{Zn}_{8}$ adjacent to the $\mathrm{Cu}$ substrate. At this stage, the thickness of the $\gamma-\mathrm{Cu}_{5} \mathrm{Zn}_{8}$ phase increases over time, while the thickness of $\varepsilon$ - $\mathrm{CuZn}_{4}$ remains practically the same. For longer wetting times, the thickness of the $\gamma-\mathrm{Cu}_{5} \mathrm{Zn}_{8}$ phase continues to increase, while $\varepsilon$-CuZn in the case of $\mathrm{Sn}-\mathrm{Zn} / \mathrm{Cu}$ couples begins to disappear and grows very little in the case of $\mathrm{Sn}-\mathrm{Zn}-1.5 \% \mathrm{In} / \mathrm{Cu}$ couples. Moreover, just $0.5 \%$ of In is sufficient to keep the $\varepsilon$-CuZn stable even after $60 \mathrm{~min}$ of wetting (Figures 6 and 7), as we observed earlier [15]. The bright spots between the $\varepsilon$ - $\mathrm{CuZn}_{4}$ and $\gamma-\mathrm{Cu}_{5} \mathrm{Zn}_{8}$ in Figure 6 are, according to EDS analysis, composed mostly of Sn with In content somewhat higher than the In content in the Sn-Zn-In solder.

According to the Gibbs phase rule, a maximum of three phases can coexist in equilibrium under the conditions of constant pressure and temperature $(T, p=$ const) in a threecomponent system. Although the solder/substrate interfaces are not under equilibrium conditions, it can be assumed that, as wetting time increases, $\mathrm{Sn}-\mathrm{Zn} / \mathrm{Cu}$ couples are getting closer to equilibrium. This might explain why, after $60 \mathrm{~min}$, three phases coexist in the $\mathrm{Sn}-\mathrm{Zn} / \mathrm{Cu}$ couples. These phases are liquid (solder), $\mathrm{Cu}_{5} \mathrm{Zn}_{8}$, and $\mathrm{Cu}$ (substrate). The addition of the fourth component, In in the present case, allows the fourth phase to coexist $\left(\mathrm{CuZn}_{4}\right.$ in the present case).

In the course of the experiment, Sn, Zn, and In diffuse from the liquid solder towards the solid $\mathrm{Cu}$, while $\mathrm{Cu}$ diffuses in the opposite direction. As a result of diffusion and 


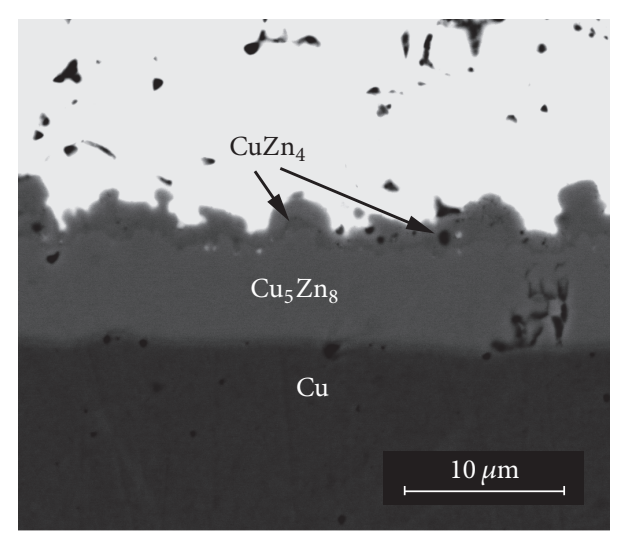

(a)

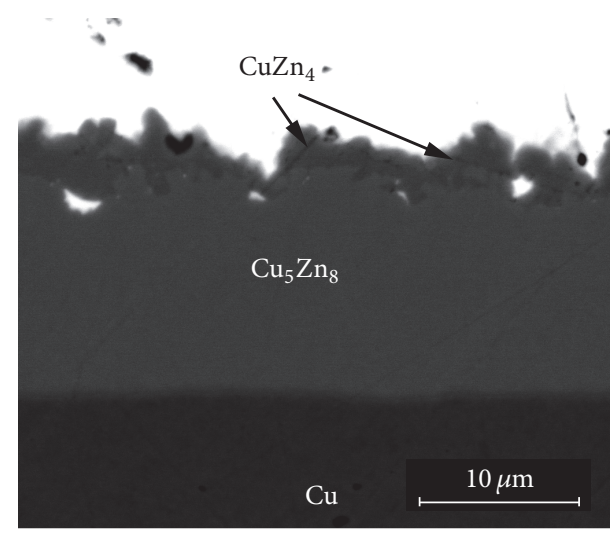

(b)

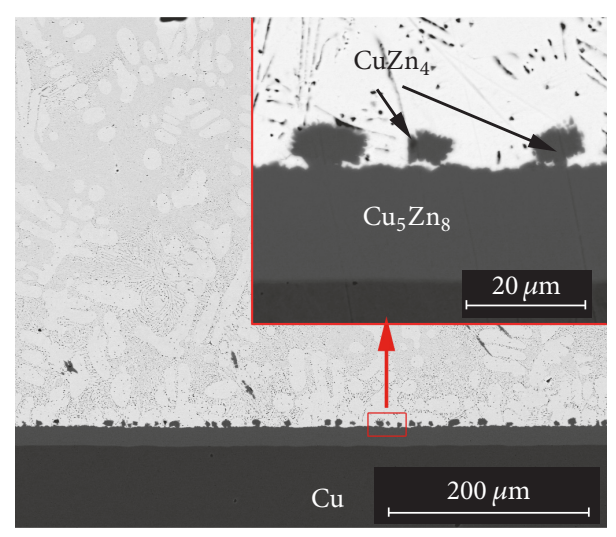

(c)

Figure 3: Interfacial microstructure of $\mathrm{Sn}-\mathrm{Zn} / \mathrm{Cu}$ couples, $T=250^{\circ} \mathrm{C}$, reflow time: (a) $3 \mathrm{~min}$, (b) $15 \mathrm{~min}$, and (c) $30 \mathrm{~min}$.

reactions between the liquid solder and solid substrate, one or more intermetallic layers are formed at the solder/substrate interface. As explained earlier [22], at the earliest stage of wetting $\varepsilon-\mathrm{CuZn}_{4}$ appears first, and only after $30 \mathrm{~s}$ of wetting can the $\gamma-\mathrm{Cu}_{5} \mathrm{Zn}_{8}$ be distinguished. Diffusion processes continue and lead to the increased thickness of intermetallic layer(s). Moreover, the $\gamma-\mathrm{Cu}_{5} \mathrm{Zn}_{8}$ is thermodynamically more stable than $\varepsilon-\mathrm{CuZn}_{4}$, so it can be speculated that, for Sn$\mathrm{Zn} / \mathrm{Cu}$ couples, after $15 \mathrm{~min}$ the $\varepsilon-\mathrm{CuZn}_{4}$ transforms to $\gamma$ $\mathrm{Cu}_{5} \mathrm{Zn}_{8}$. This can be expressed as the reaction $5 \mathrm{CuZn}_{4} \rightarrow$ $\mathrm{Cu}_{5} \mathrm{Zn}_{8}+12 \mathrm{Zn}$. The freed $\mathrm{Zn}$ atoms go to the liquid solder, locally increasing $\mathrm{Zn}$ concentration near the interface. In the case of $(\mathrm{Sn}-\mathrm{Zn})_{\text {eut }}+1.5 \% \mathrm{In} / \mathrm{Cu}$ couples, In atoms diffusing through the $\varepsilon-\mathrm{CuZn} n_{4}$ layer towards substrate may stop at the $\varepsilon-\mathrm{CuZn} \mathrm{n}_{4} / \gamma-\mathrm{Cu}_{5} \mathrm{Zn}_{8}$ interface. Earlier, we discussed the growth mechanism of intermetallic layers at the Sn-Zn$\mathrm{Cu} / \mathrm{Cu}$ interface [22] as a result of $\mathrm{Cu}$ and $\mathrm{Zn}$ diffusion in the opposite direction. It is possible that the indium atoms form a kind of diffusion barrier for $\mathrm{Cu}$ diffusing towards the solder, but not a barrier for $\mathrm{Zn}$ diffusing towards the substrate. As a result, the $\varepsilon-C u Z n_{4}$ does not disappear after a prolonged time for $\mathrm{Sn}-\mathrm{Zn}$-In/Cu couples, but neither does its thickness increase substantially.
Evolution of intermetallic layer thickness with time is described with [23-25]

$$
\delta=k e^{-\mathrm{Q} / R T} t^{n},
$$

where $\delta$ is the thickness of the intermetallic layer $[\mu \mathrm{m}], k$ is the growth constant, $Q$ is the activation energy of growth $[\mathrm{kJ} / \mathrm{mol}], R$ is the universal gas constant $[8.314 \mathrm{~J} / \mathrm{mol}], T$ is soldering temperature $[\mathrm{K}], t$ is soldering time [min.], and $n$ is the time exponent.

Figure 8 illustrates the growth kinetics of $\varepsilon$ - $\mathrm{CuZn}_{4}$ and $\gamma-\mathrm{Cu}_{5} \mathrm{Zn}_{8}$ for $(\mathrm{Sn}-\mathrm{Zn})_{\text {eut }}$ and $(\mathrm{Sn}-\mathrm{Zn})_{\text {eut }}+1.5 \mathrm{at} \%$ In in comparison to literature data $[26,27]$. It is clear that the growth constant of the $\gamma-\mathrm{Cu}_{5} \mathrm{Zn}_{8}$ phase $(k=3.18)$ in the case of $\mathrm{Sn}-\mathrm{Zn} / \mathrm{Cu}$ is the same as in the case of $\mathrm{Sn}-\mathrm{Zn}-1.5 \% \mathrm{In} / \mathrm{Cu}$ and is more than ten times higher than the growth constant of the $\varepsilon-\mathrm{CuZn}$ phase. The present $k$ of the $\gamma-\mathrm{Cu}_{5} \mathrm{Zn}_{8}$ phase is slightly higher than that reported in [26]. On the other hand, it can be assumed that growth constant $k$ increases with temperature, since for $\mathrm{Sn}-\mathrm{Zn} / \mathrm{Cu}$ at $230^{\circ} \mathrm{C}$ the reported $k$ is 1.72 .

In order to determine the activation energy of the growth of the $\gamma-\mathrm{Cu}_{5} \mathrm{Zn}_{8}$ phase, samples were held at 230, 250, 280, and $320^{\circ} \mathrm{C}$ for $8 \mathrm{~min}$. Figure 9 illustrates the relation between 


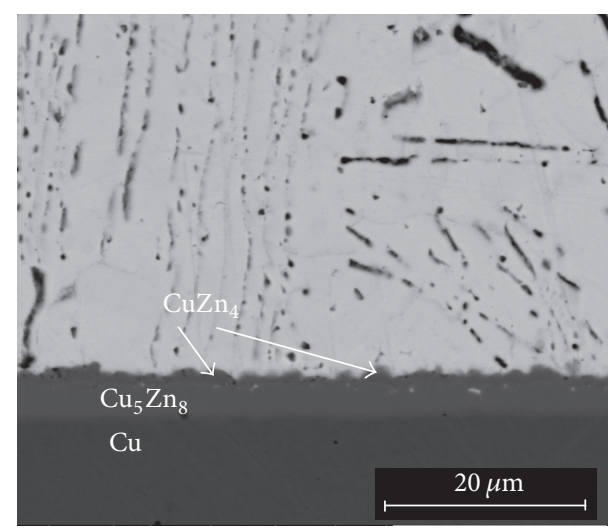

(a)

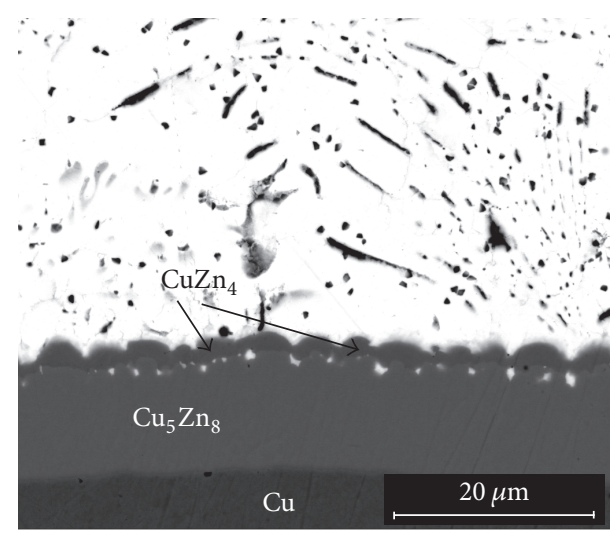

(b)

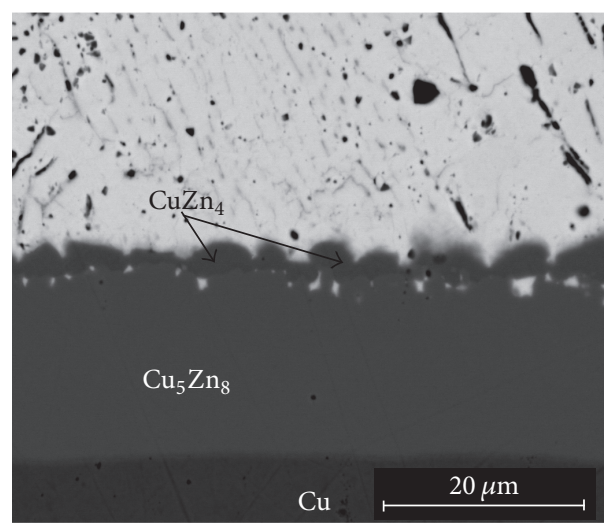

(c)

FIgURE 4: Interfacial microstructure of Sn-Zn-1.5\% In/Cu couples, $T=250^{\circ} \mathrm{C}$, reflow time: (a) $3 \mathrm{~min}$, (b) $15 \mathrm{~min}$, and (c) $30 \mathrm{~min}$.

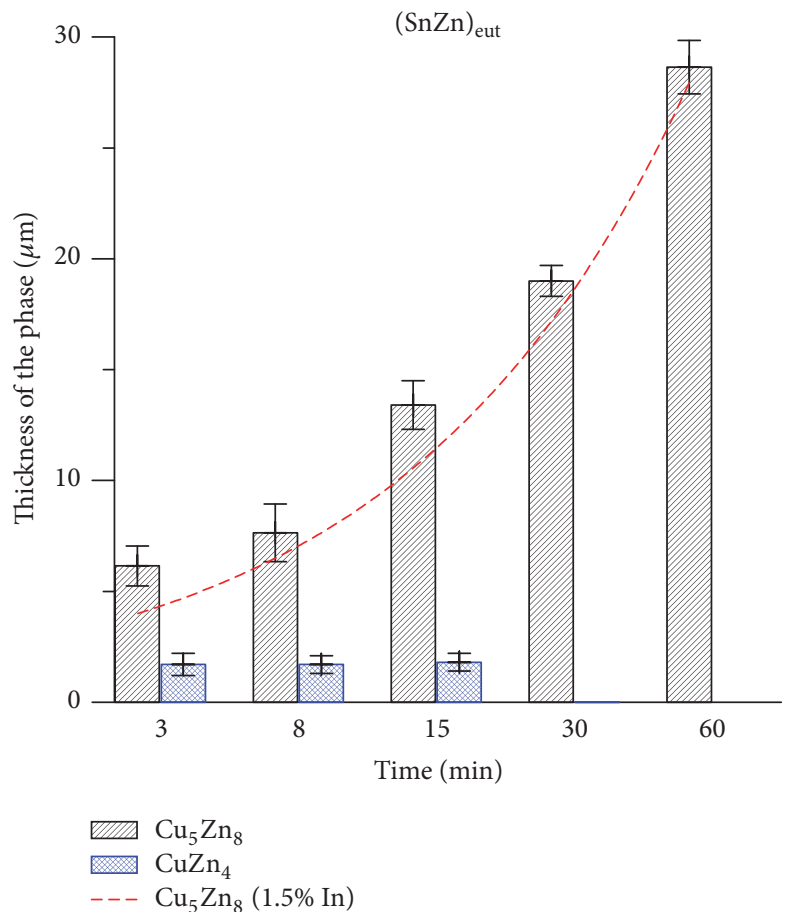

(a)

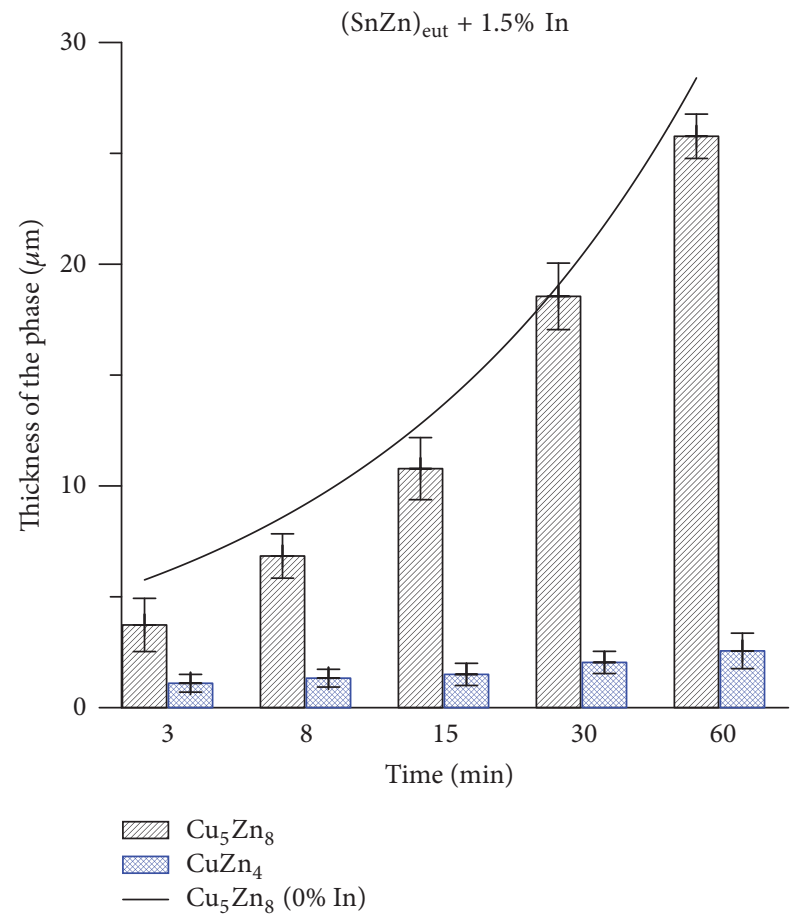

(b)

Figure 5: Thickness of intermetallic layers $\left(\mathrm{Cu}_{5} \mathrm{Zn}_{8}, \mathrm{CuZn}_{4}\right)$ at $(\mathrm{Sn}-\mathrm{Zn})_{\text {eut }} / \mathrm{Cu}$ and $(\mathrm{Sn}-\mathrm{Zn})_{\text {eut }}+1.5 \% \mathrm{In} / \mathrm{Cu}$ interface at $250^{\circ} \mathrm{C}$. 


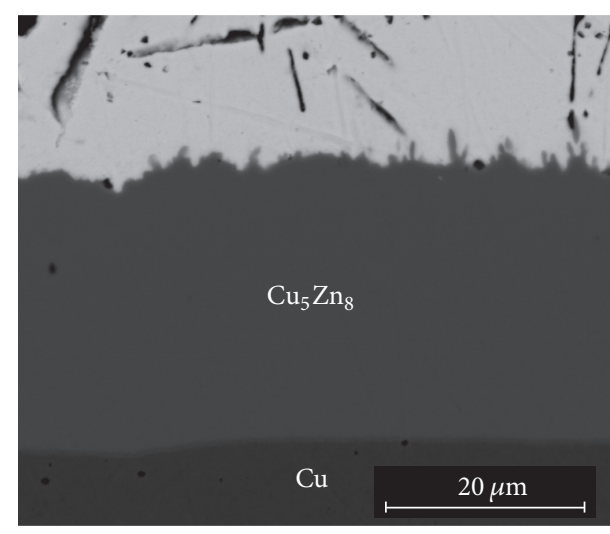

(a)

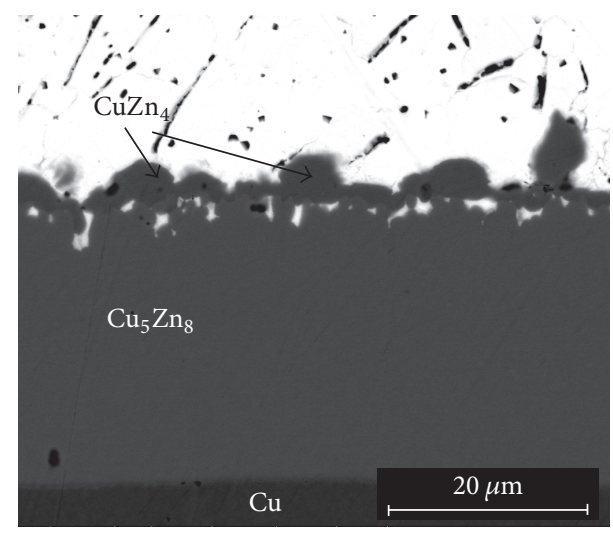

(b)

Figure 6: Interfacial microstructures of (a) $\mathrm{Sn}-\mathrm{Zn} / \mathrm{Cu}$ couples and (b) $\mathrm{Sn}-\mathrm{Zn}-0.5 \% \mathrm{In} / \mathrm{Cu}$ couples, $\mathrm{T}=250^{\circ} \mathrm{C}$, reflow time $60 \mathrm{~min}$.

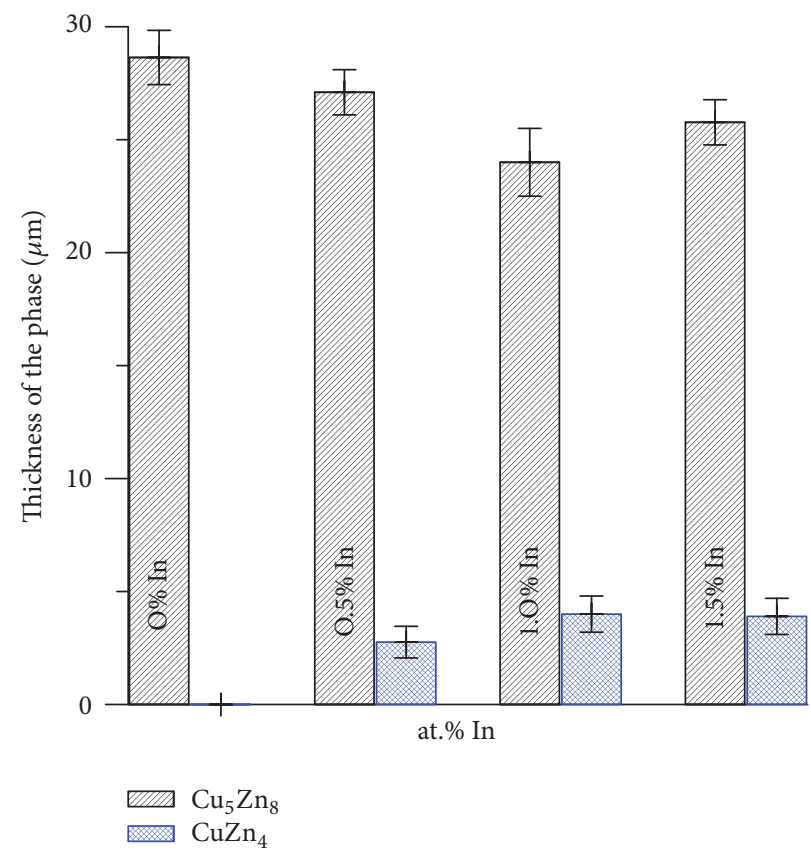

Figure 7: Thickness of the $\mathrm{CuZn}_{4}$ and $\mathrm{Cu}_{5} \mathrm{Zn}_{8}$ intermetallic layers at the $(\mathrm{Sn}-\mathrm{Zn})_{\text {eut }}+x \mathrm{In} / \mathrm{Cu}(x=0,0.5,1,1.5 \%)$ interfaces after 60 min at $250^{\circ} \mathrm{C}$.

the growth rate and reciprocal soldering temperature, according to (3). The activation energy of growth of the phase is, according to our results, equal to $29.5 \mathrm{~kJ} / \mathrm{mol}$, which is close to $26 \mathrm{~kJ} / \mathrm{mol}$ reported in [26].

$$
\ln \delta=\ln k+n \ln t-\frac{Q}{R T}
$$

\section{Conclusion}

Wettability studies of $\mathrm{Sn}-\mathrm{Zn}$ eutectic doped with $\mathrm{In}$ on $\mathrm{Cu}$ substrate were performed in the presence of flux over a temperature range of $230-370^{\circ} \mathrm{C}$ for wetting times in the of range 3-60 min. It was found that additions of indium lower the wetting angle, but the wetting time does not affect the wetting angle.

The microstructure of solidified solder/Cu interfaces was investigated with scanning electron microscopy. Two intermetallic phases are observed at the interface: $\varepsilon$-CuZn on the side of the solder and $\gamma-\mathrm{Cu}_{5} \mathrm{Zn}_{8}$ adjacent to the $\mathrm{Cu}$ substrate. At the early stage (up to $15 \mathrm{~min}$ ), the thickness of the $\gamma-\mathrm{Cu}_{5} \mathrm{Zn}_{8}$ phase increases much faster. For longer wetting times, greater than $15 \mathrm{~min}$, the thickness of the $\gamma-\mathrm{Cu}_{5} \mathrm{Zn}_{8}$ phase continues to increase, while $\varepsilon$ - $\mathrm{CuZn}_{4}$ in the case of Sn$\mathrm{Zn} / \mathrm{Cu}$ couples begins to disappear and grows very little in the case of $\mathrm{Sn}-\mathrm{Zn}-1.5 \% \mathrm{In} / \mathrm{Cu}$ couples. Therefore, the addition of indium to $\mathrm{Sn}-\mathrm{Zn}$ solder stabilises $\varepsilon-\mathrm{CuZn}_{4}$ at the interface of solder and substrate, even after $60 \mathrm{~min}$ of wetting. 


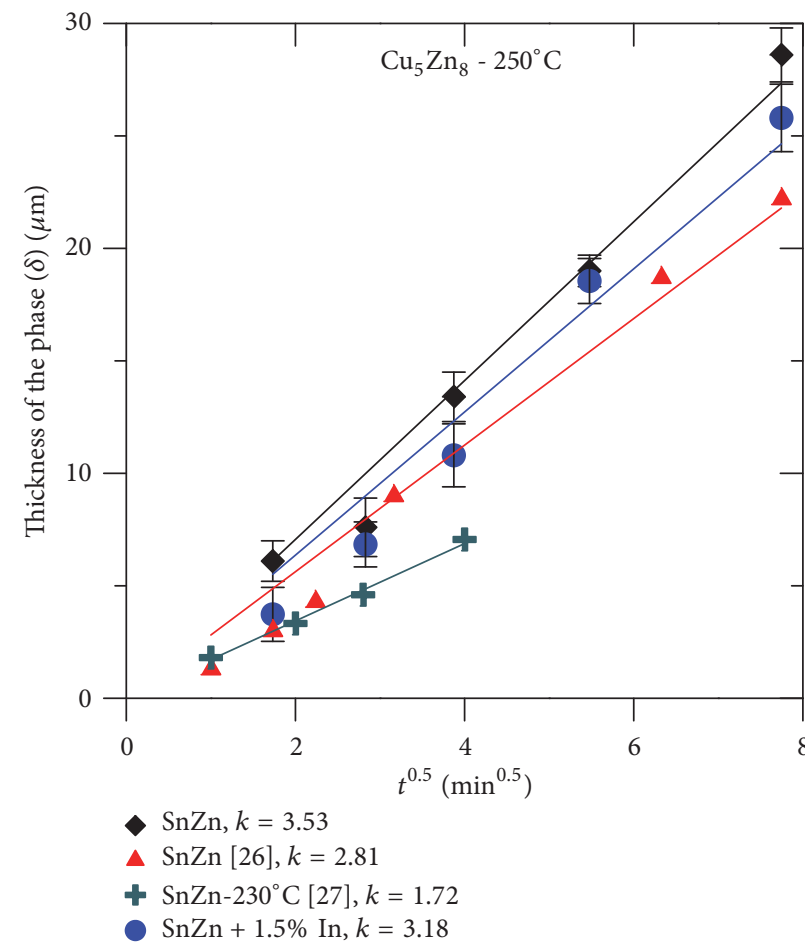

(a)

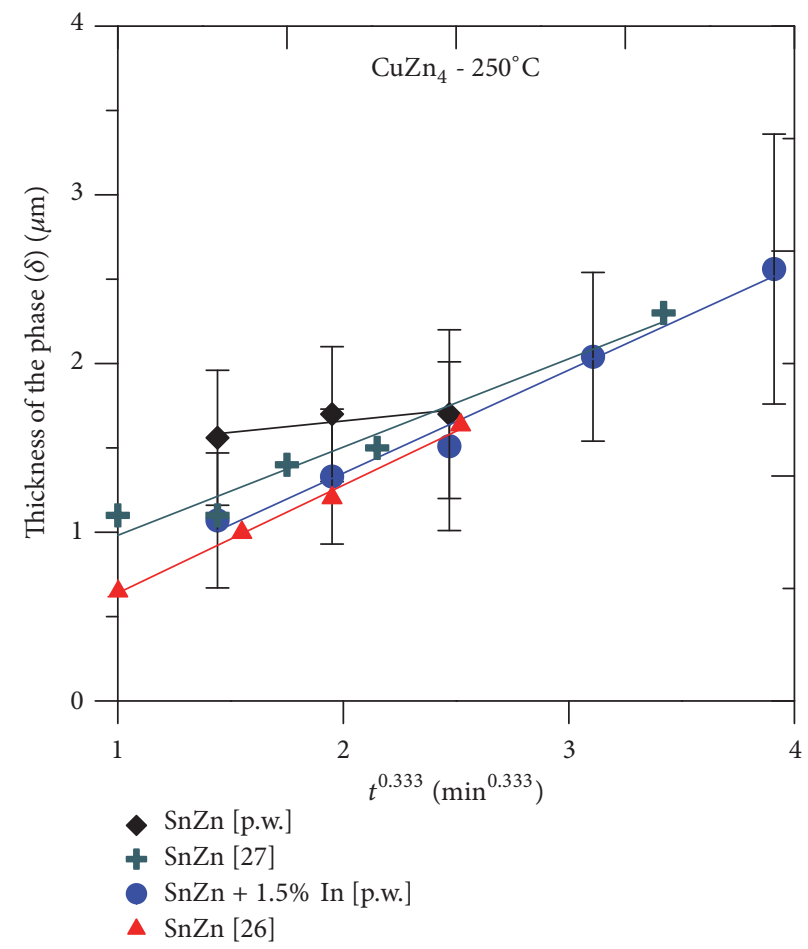

(b)

FIGURE 8: Growth kinetics of $\varepsilon$ - $\mathrm{CuZn}_{4}$ (a) and $\gamma-\mathrm{Cu}_{5} \mathrm{Zn}_{8}$ (b) at $250^{\circ} \mathrm{C}$, for $(\mathrm{Sn}-\mathrm{Zn})_{\text {eut }} / \mathrm{Cu}$ and $(\mathrm{Sn}-\mathrm{Zn})_{\text {eut }}+1.5 \% \mathrm{In} / \mathrm{Cu}$ interfaces. Present work (p.w.) and [26] at $250^{\circ} \mathrm{C}$, [27] at $230^{\circ} \mathrm{C}$.

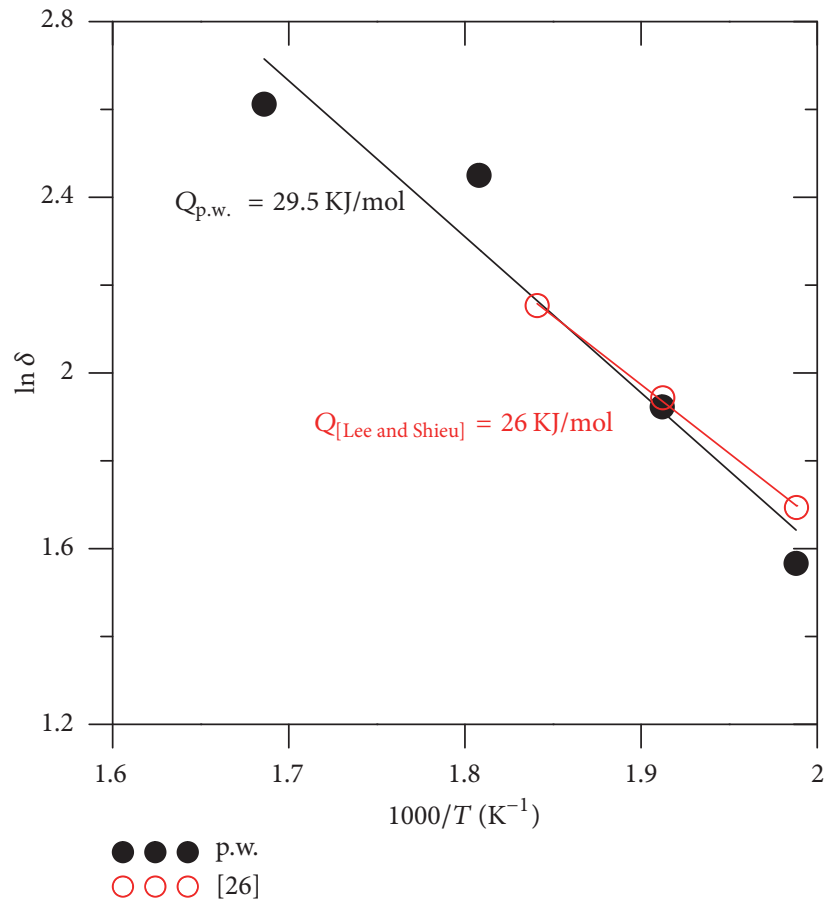

FiguRE 9: Arrhenius plot for the activation energy of $\mathrm{Cu}_{5} \mathrm{Zn}_{8}$ phase layer at the interface between molten $(\mathrm{Sn}-\mathrm{Zn})_{\text {eut }}[26]$ or molten $(\mathrm{Sn}-\mathrm{Zn})_{\text {eut }}$ + In [present work -p.w.] and Cu. 


\section{Conflicts of Interest}

The authors declare that there are no conflicts of interest regarding the publication of this article.

\section{Acknowledgments}

This work was financed within the framework of the Project POIG.01.01.02-00-015/09 (advanced materials and their production technologies, ZAMAT), cofunded by the European Regional Development Fund (ERDF).

\section{References}

[1] Directive 2002/96/WE of European Parliament and Council of 27/01/2003,.

[2] Directive 2003/108/WE of European Parliament and Council of 08/12/2003,

[3] Directive 2008/35/WE of European Parliament and Council of $11 / 03 / 2008$,

[4] L. Zhang and K. N. Tu, "Structure and properties of lead-free solders bearing micro and nano particles," Materials Science and Engineering: R: Reports, vol. 82, pp. 1-32, 2014.

[5] S. Liu, S.-B. Xue, P. Xue, and D.-X. Luo, "Present status of $\mathrm{Sn}-\mathrm{Zn}$ lead-free solders bearing alloying elements," Journal of Materials Science: Materials in Electronics, vol. 26, no. 7, pp. 4389-4411, 2015.

[6] X. Wei, H. Huang, L. Zhou, M. Zhang, and X. Liu, "On the advantages of using a hypoeutectic $\mathrm{Sn}-\mathrm{Zn}$ as lead-free solder material," Materials Letters, vol. 61, no. 3, pp. 655-658, 2007.

[7] P. Xue, S.-B. Xue, Y.-F. Shen, and H. Zhu, "Interfacial microstructures and mechanical properties of Sn-9Zn-0.5Ga$\mathrm{xNd}$ on $\mathrm{Cu}$ substrate with aging treatment," Materials and Design, vol. 60, pp. 1-6, 2014.

[8] L. Zhang, S. B. Xue, L. L. Gao et al., "Development of SnZn lead-free solders bearing alloying elements," Journal of Materials Science: Materials in Electronics, vol. 21, no. 1, pp. 1$15,2010$.

[9] J. Glazer, "Metallurgy of low temperature pb-free solders for electronic assembly," International Materials Reviews, vol. 40, no. 2, pp. 65-93, 1995.

[10] B. P. Richards and K. Nimmo, Lead-free Soldering-Update, Department of Trade and Industry, Lead-free SolderingUpdate, UK, 2000.

[11] A. A. El-Daly and A. E. Hammad, "Elastic properties and thermal behavior of $\mathrm{Sn}-\mathrm{Zn}$ based lead-free solder alloys," Journal of Alloys and Compounds, vol. 505, no. 2, pp. 793-800, 2010.

[12] S. Ganesan and M. Pecht, "Lead-free Electronics," Lead-free Electronics, pp. 1-766, 2006.

[13] P. Šebo, Z. Moser, P. Švec et al., "Effect of indium on the microstructure of the interface between Sn3.13Ag0.74CuIn solder and $\mathrm{Cu}$ substrate," Journal of Alloys and Compounds, vol. 480, no. 2, pp. 409-415, 2009.

[14] P. Fima, T. Gancarz, J. Pstruś, and A. Sypień, "Wetting of SnZn-xIn (x = 0.5, 1.0, $1.5 \mathrm{wt} \%)$ alloys on cu and Ni substrates," Journal of Materials Engineering and Performance, vol. 21, no. 5, pp. 595-598, 2012.

[15] T. Gancarz, P. Fima, and J. Pstruś, “Thermal expansion, electrical resistivity, and spreading area of Sn-Zn-In alloys," Journal of
Materials Engineering and Performance, vol. 23, no. 5, pp. 15241529, 2014

[16] Z. Moser, W. Gașior, J. Pstruś, I. Kaban, and W. Hoyer, “Thermophysical properties of liquid In-Sn alloys," International Journal of Thermophysics, vol. 30, no. 6, pp. 1811-1822, 2009.

[17] J. Pstruś, P. Fima, and T. Gancarz, "Wetting of $\mathrm{Cu}$ and $\mathrm{Al}$ by Sn$\mathrm{Zn}$ and $\mathrm{Zn}-\mathrm{Al}$ eutectic alloys," Journal of Materials Engineering and Performance, vol. 21, no. 5, pp. 606-613, 2012.

[18] J. Pstruś, "Surface tension and density of liquid In-Sn-Zn alloys," Applied Surface Science, vol. 265, pp. 50-59, 2013.

[19] H. M. O. Lee, S. W. Yoon, and B.-J. Lee, "Thermodynamic prediction of interface phases at $\mathrm{Cu}$ /solder joints," Journal of Electronic Materials, vol. 27, no. 11, pp. 1161-1166, 1998.

[20] M. Date, K. N. Tu, T. Shoji, M. Fujiyoshi, and K. Sato, "Interfacial reactions and impact reliability of $\mathrm{Sn}-\mathrm{Zn}$ solder joints on $\mathrm{Cu}$ or electroless $\mathrm{Au} / \mathrm{Ni}(\mathrm{P})$ bond-pads," Journal of Materials Research, vol. 19, no. 10, pp. 2887-2896, 2004.

[21] Y.-C. Huang, S.-W. Chen, C.-Y. Chou, and W. Gierlotka, "Liquidus projection and thermodynamic modeling of Sn-ZnCu ternary system," Journal of Alloys and Compounds, vol. 477, no. 1-2, pp. 283-290, 2009.

[22] P. Fima, J. Pstruś, and T. Gancarz, "Wetting and interfacial chemistry of $\mathrm{SnZnCu}$ alloys with $\mathrm{Cu}$ and $\mathrm{Al}$ substrates," Journal of Materials Engineering and Performance, vol. 23, no. 5, pp. 1530-1535, 2014.

[23] R. J. Klein Wassink, Soldering in Electronics, Electrochemical Publications Ltd., Ayr, Scotland, 1989.

[24] P. T. Vianco, J. A. Rejent, and P. F. Hlava, "Solid-state intermetallic compound layer growth between copper and 95.5Sn-3.9Ag$0.6 \mathrm{Cu}$ solder," Journal of Electronic Materials, vol. 33, no. 9, pp. 991-1004, 2004.

[25] A. R. Fix, G. A. López, I. Brauer, W. Nüchter, and E. J. Mittemeijer, "Microstructural development of Sn-Ag-Cu solder joints," Journal of Electronic Materials, vol. 34, no. 2, pp. 137-142, 2005.

[26] C. S. Lee and F. S. Shieu, "Growth of intermetallic compounds in the Sn-9Zn/Cu joint," Journal of Electronic Materials, vol. 35, no. 8, pp. 1660-1664, 2006.

[27] Y. C. Chan, M. Y. Chiu, and T. H. Chuang, "Intermetallic compounds formed during the soldering reactions of eutectic Sn-9Zn with $\mathrm{Cu}$ and Ni substrates," Zeitschrift für Metallkunde, vol. 93, no. 2, pp. 95-98, 2002. 

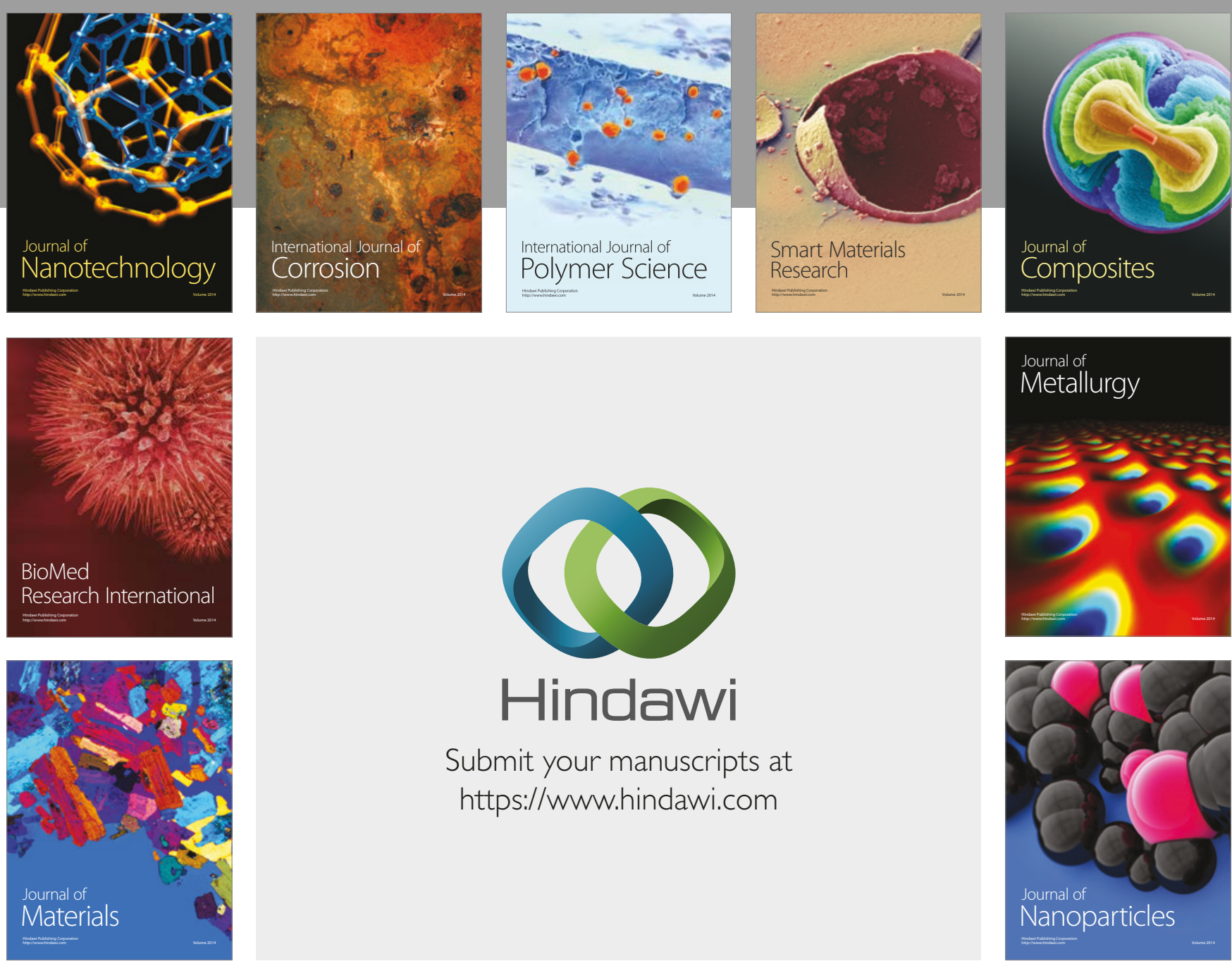

\section{Hindawi}

Submit your manuscripts at

https://www.hindawi.com
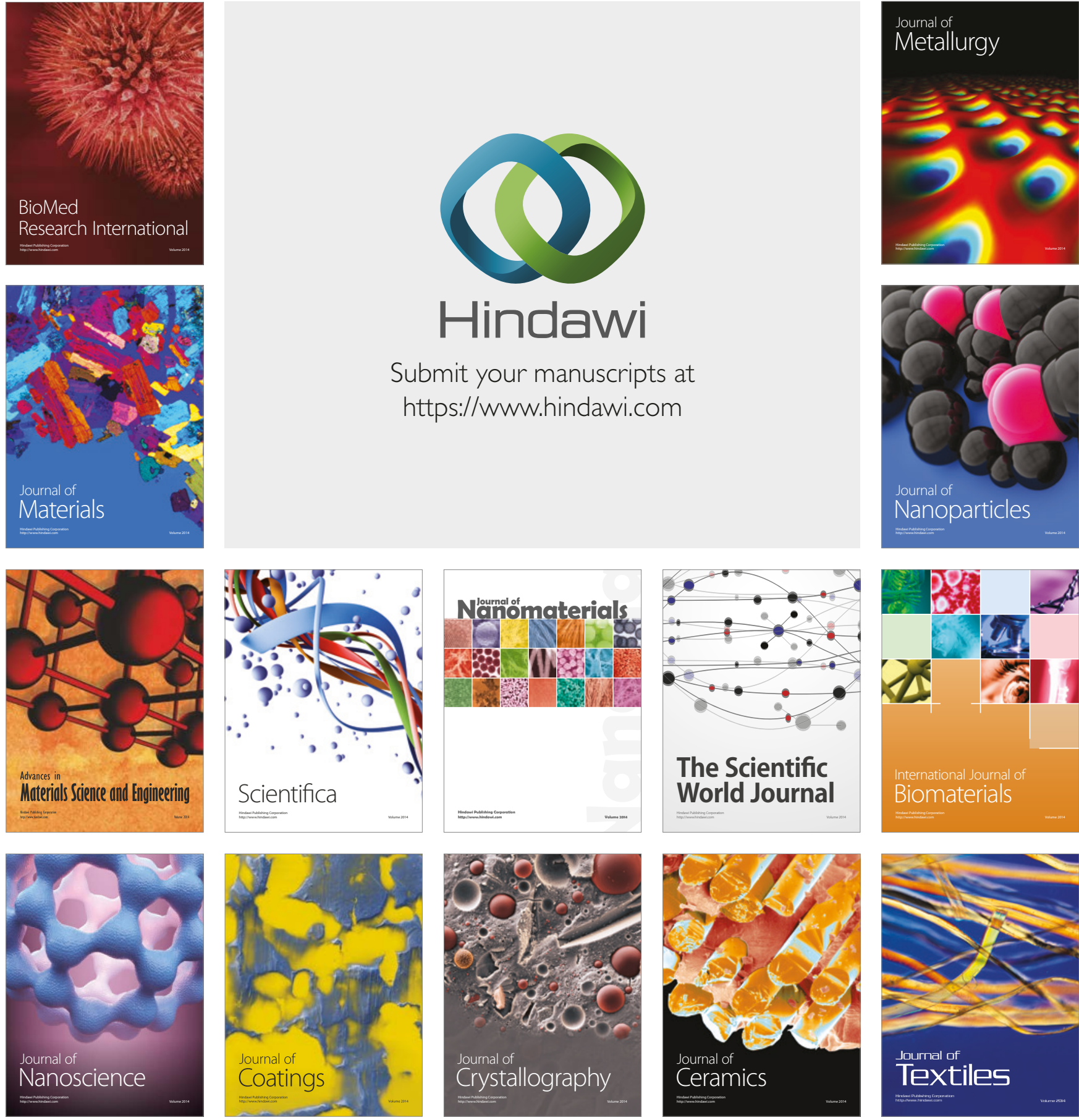

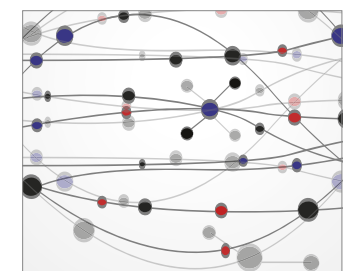

The Scientific World Journal
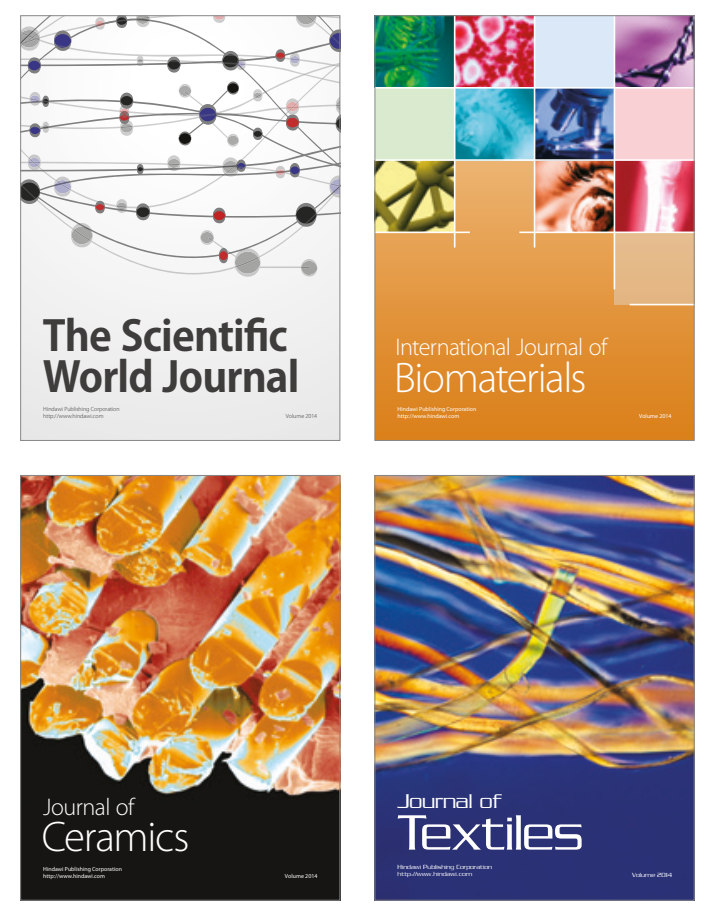